\title{
The effect of solvency, activity and implementation of good corporate governance on profitability
}

\author{
Yan Nasution ${ }^{1 *}$, Citra Sukmadilaga ${ }^{2}$ \\ 1 Pakuan University, Bogor, Indonesia \\ 2 Padjadjaran University, Sumedang, Indonesia
}

\section{Keywords \\ Solvency \\ Activity \\ GCG \\ Profitability}

Received: 3 December 2018

Accepted: 1 January 2019

Published: 20 February 2019

\begin{abstract}
The aim of this research is to find out the effect of solvency, activity, and implementation of good corporate governance on the profitability of non-banking state-owned enterprises, which the IPO before 2012 and registered in Indonesia Stock Exchange in 2012 until 2017. The number of the research sample was 14 companies. The phenomenon of operational inefficiency of the company resulted in the loss of several state-owned enterprises in that period. In this study, profitability indicators use Return On Assets (ROA). While the debt of the state-owned enterprises is increasingly swollen, especially those who get government assignments are feared that they will default. This is related to solvency as measured by using the Debt to Equity Ratio (DER). In comparison, the inefficiency of companies in using and managing assets owned will only increase the company's burden in the form of investment that does not bring profit. This is related to the activities measured by using Total Assets Turnover (TATO). The last is Good Corporate Governance (GCG), where corporate governance is seen as not yet optimal by StateOwned Enterprise. As for corporate governance using the Audit Committee indicators. Based on the study results, it is concluded that DER, TATO, and GCG with the Audit Committee indicators have a significant effect on ROA in State-Owned Enterprise registered on the IDX. The same result is also with partial test ( $t$ test), where DER has a significant effect on ROA, TATO has a significant effect on ROA, and GCG with the Audit Committee indicator has a significant effect on ROA. The findings imply that to reduce the level of debt, the state-owned enterprises should efficiently use their assets and maintain and enhance competent audit committees.
\end{abstract}

(C) 2019 The Author(s). Published by TAF Publishing.

\section{INTRODUCTION}

In maintaining the sustainability of the company according to the going concern principle, every company must be able to produce a maximum profit, because profit is the main measure of efficiency and success of a company (Liu, Fisher, \& Chen, 2018; Song, Cai, \& Feng, 2017). Likewise from the investor's point of view, one of the important indicators to assess the company's future prospects is how far the company is able to create profit growth or profitability (Endang \& Risal, 2017; Khan \& Khokhar, 2015). Whereas (Hermuningsih, 2013; Sundar \& Al Harthi, 2015) stated that profitability describes whether a company has good opportunities or prospects in the future, which is the higher the profitability of the company, then the company's ability to maintain its survival will be guaranteed.

To find out how far the company is able to produce profits, it cannot be separated from the company's financial performance itself and to find out the company's financial performance related to its profitability, there are various profitability ratios that can be used to assess financial health and the company's ability to produce profits, including the use of ROA and Return on Equity (ROE) as indicators of financial performance (Putra \& Nuzula, 2017; Willy, 2017). During this time based on the facts, most studies are oriented to ROE (Cîrciumaru, Siminica, \& Marcu, 2010; Zahra \& Hayton, 2008) even practitioners such as analysts and

* corresponding author: Yan Nasution

†email: yannoviar@unpak.ac.id 
Wall Street investors tend to focus on ROE rather than ROA as the main measure of company performance. This is because this ratio provides metrics that are fast and easily understood by investors. But behind that it turns out that ROE can obscure a lot of potential problems in the company and ROE can distract from business fundamentals leading to unpleasant surprises. This means that companies can use financial strategies to maintain a healthy ROE artificially for a while and hide the deteriorating performance in its business fundamentals (Bahri, Mahsina, \& Poniwati, 2017; Hagel, Brown, \& Davison, 2010).

Based on the description above, this study focuses on ROA profitability indicators to analyze long-term profitability trends in all Non-banking state-owned enterprises (BUMN) registered in the Indonesia Stock Exchange (IDX) (Bursa Efek Indonesia, 2018) from 2012 to 2017. This supported by the results of research Kiel and Nicholson (2003) which stated the performance measurement based on accounting which is commonly used is ROA. While the selection of Nonbank State Owned Enterprises in this study was due to the rarely of studies using SOEs as the subject of their research. The phenomenon related to the company's ability to produce profits, which was in 2015 the Ministry of state-owned enterprises proposed the addition of State Capital Participation (PMN) to 25 state-owned companies to improve their performance, which 5 were SOEs that have been going public (Wiyanti, 2015). Likewise in the first semester of 2017 as many as 24 state-owned enterprises recorded a loss of around Rp. 5 trillion and the causes are varied from carrying out government assignments to operational inefficiencies of the company resulting in losses (Alfian \& Tresna, 2017; Ariyanti, 2017).

Another fact is that there are 20 SOE's that have been going public on the Indonesia Stock Exchange. From the 20 companies, their performance can be seen with the ROA indicator presented in the following chart.

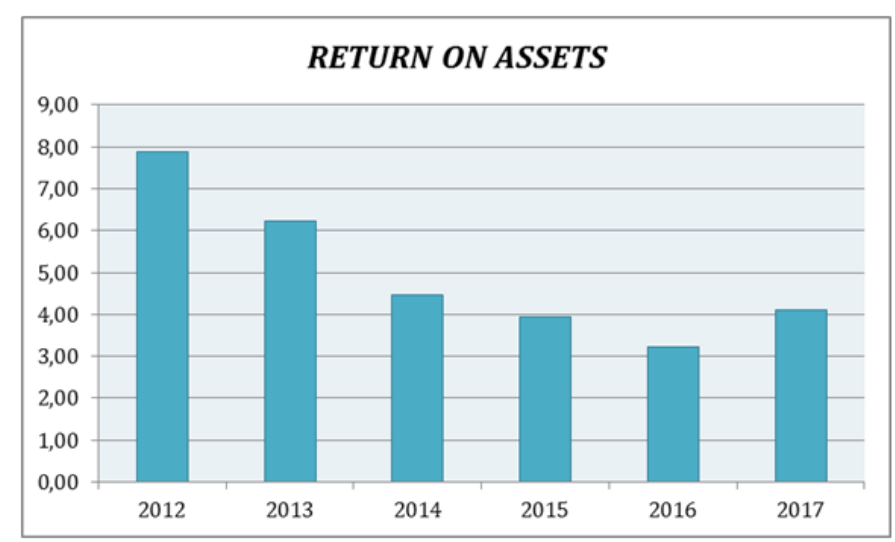

FIGURE 1. State Owned Enterprises (SOEs) with ROA indicator in 2012-2017 (Source: (World Bank, 2017)

Based on Figure 1 above, it can be seen that the performance of state-owned companies registered on the Indonesia Stock Exchange with ROA indicator values has decreased from 2012 to 2017. The decreasing in ROA is an important and interesting thing to study, which is the SOEs should have the ability to achieve financial performance which is better and has a consistent growth rate compared to non-SOEs companies. This is based on the number of assets owned, which the strength of the assets owned is the initial capital to achieve the optimal performance if the assets owned are managed properly.

The downward trend in SOEs' financial performance is supposed related to the company's ability to pay its longterm obligations including interest and principal debt (Choi, O'Hanlon, \& Pope, 2006; Sulashvili et al., 2017). To make sure the cause of the decreasing in SOE's ROA, first used the solvency ratio which provides a general description of debt in the company's capital structure. This means that there is a close relationship between solvency ratios and profitability (Gitman, 2002; San \& Heng, 2011).

There are several ratios in the group of solvency ratio, but what is taken in this study is the DER ratio. This is because Debt to Equity Ratio can show the percentage of funds provided by shareholders to lenders. The higher the ratio, the lower the company funding provided by shareholders as well as vice versa. Debt to Equity Ratio with a number below 1.00 , indicates that the company has a debt that is smaller than its capital, but as investors we must also be smart in analyzing this DER, because if the total debt is greater than capital, then we must look further whether current debt or larger long-term debt. Some previous research has stated that DER does not significantly influence on profitability 
(Andreani, 2014), this is in line with the research (Tailab, 2014) stated that Debt to Equity does not have a significant impact on the company's ROA performance and while the results of the study (Rahman, 2017), stateding otherwise there is a negative relationship between the two solvency ratios and ROA. Based on the description above, it can be concluded that DER does not affect ROA as well as when it is viewed from the context of the relationship between the two variables, the relationship is negative.

In fact to the debt of the state-owned enterprises continues to rise in the period of 2012 to 2017, especially the SOEs that get government assignments is feared that they would default on their debts. Moreover, revenue from projects assigned by the government does not have large returns for the SOEs themselves, especially construction SOEs are not economically feasible (Edward, 2015).

Another thing related to the decreasing in the financial performance of SOEs the writer tried to measure the efficiency and effectiveness of asset utilization in order to earn income. In this case the ratio used is the activity ratio which the activity ratio that is chosen is the ratio of TATO. This ratio is used to measure the ability of funds embedded in the entire rotating assets in a period or the ability of the capital invested in produceing "revenue". This is in line with Warrad and Rania (2015) stated that the Total Asset Turnover ratio is the ratio used to measure the turnover of all assets owned by a company and measure how much sales are obtained from each rupiah of assets. Furthermore this is supported by the results of the statement (Mondal \& Ghosh, 2012). It is the ratio of total turnover to total assets. This ratio is used to control for the impact of total assets on corporate performance.

A high TATO ratio usually shows good management, whereas a low ratio forces management to evaluate its marketing strategy and capital expenditure. The same amount of assets can increase sales volume if the total asset turnover is increased or enlarged, so the total asset turnover can play a role in determining ROA. This is supported by the results of research by (Andreani, 2014; Enekwe, 2015) which is stated that total asset turnover ratio has a positive influence on profitability.

Based on the description above, it can be concluded that the more efficient a company is using its assets to obtain income, the better profit it will show that will be received, and vice versa, the inefficiency of the company in using the assets owned will only increase the burden of the company in the form of investment that does not bring profit.

In fact, according to SOEs' Minister Rini Soemarno, that up to the end of 2017, the total assets of SOEs reached more than Rp. 7,200 trillion, assets that are less or not optimal use (idle) certainly cause costs (taxes, maintenance, etc.) that will become the burden of the company, (Pitoko, 2018). Another phenomenon related to the decreasing in the financial performance of SOEs is companies need to apply good corporate management and that can only be realized by implementing GCG. GCG has become a very interesting and popular issue lately. This arises in connection with the principal-agency theory, which is to avoid conflict between the principal and the agent. Conflict arises because the difference in interests must be managed so it is not causing any harm to the parties. Corporations are formed and constitute a separate entity that is separated and is a legal subject, so that the existence of the corporation and the interested parties (stakeholders) must be protected through the implementation of GCG (Bukti Konsistensi Pengelolaan Keuangan, 2017).

GCG is started from the Cadbury (1992) which stated that corporate governance is a series of codes of conduct to direct and control the activities of the company and its main stakeholders and be strengthened by Tomsic (2013) new perspectives in the field of corporate governance by forming a two-way relationship between companies and stakeholders, moving from collaborative building and managing relationships towardsa suitable for the exchange of ideas, knowledge and special information, and all that is needed to produce and maintain the fitness of the company.

There are some previous studies related to GCG stated that the size of the audit committee, institutional ownership and managerial ownership does not affect financial performance (Herdjiono \& Mega, 2017), this is reinforced by Zabri, Ahmad, and Wah (2016) stated that the size of the board had a significant and weak negative relationship with ROA. In contrast (Alley, Adebayo, \& Oligbi, 2016; Kallamu \& Saat, 2015; Naseem, Xiaoming, Riaz, \& Rehman, 2017) stated that corporate governance significantly affects financial performance.

Based on the description above, it can be concluded that most studies or researches stated that GCG does not affect financial performance, only a small percentage stated otherwise. This means that there is a research gap that occurs and this is very interesting to study, which is in this study the writer chose a small part by only taking 1 dimension of GCG namely the dimensions of the Audit Committee and this is one that distinguishes it from previous research.

The fact is that the implementation of GCG in Indonesia was initially voluntary so there were no sanctions, but since 2012 the Ministry of SOEs through PER12/MBU/2012 (Peraturan Menteri Bumn, 2012) requires the implementa- 
tion of GCG in SOEs' companies. But until 2015 the implementation of GCG in SOEs has not been optimal as stated by the Financial Services Authority (OJK) that the implementation of GCG in Indonesia is currently lagging behind compared to countries in the ASEAN region (Primadhyta, 2017). This is confirmed by the 2015 ASEAN Corporate Governance Awards held by the ASEAN Capital Markets Fo- rum (ACMF) in Manila Philippines, which there are only two emitents from Indonesia that are included in the list of 50 Emitents and both are not State-Owned companies, even if we see scores or GCG implementation ranking based on countries in the ASEAN Region, it is clear that Indonesia is relatively behind compared to neighboring countries, as shown in Figure 2 below.

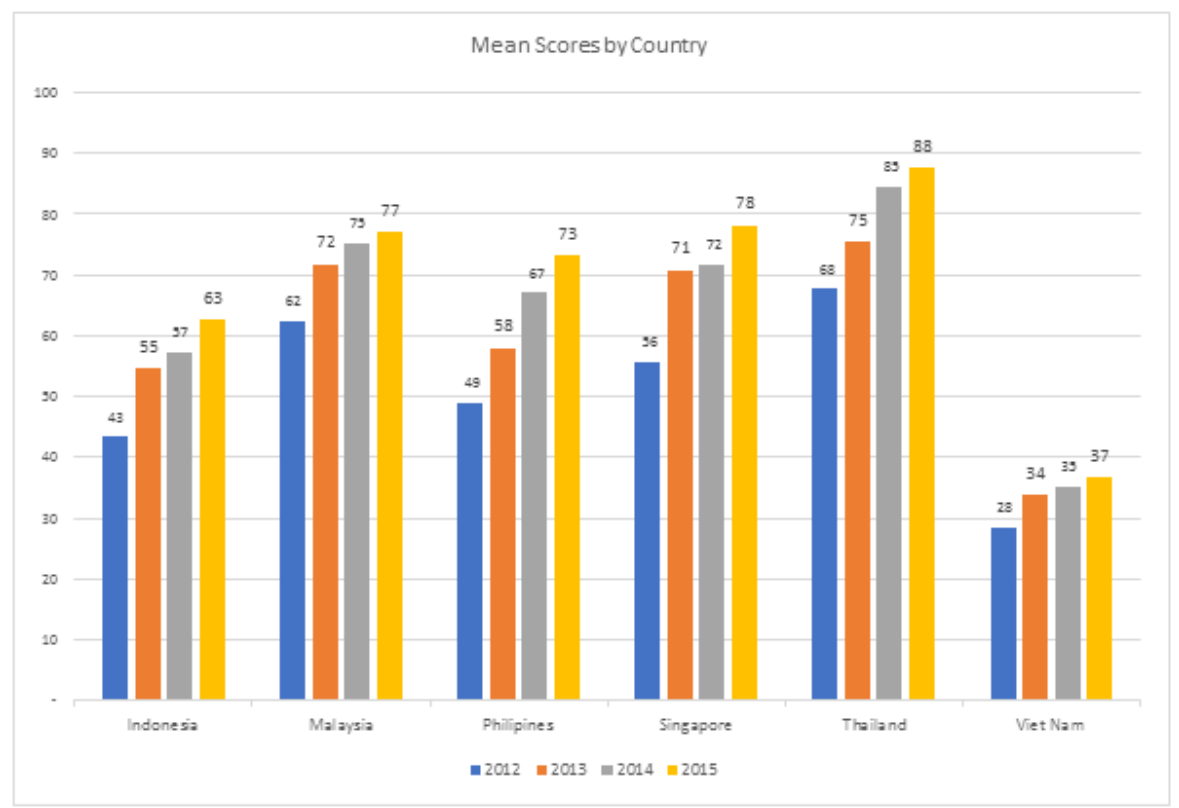

FIGURE 2. GCG average score by country year 2012-2015 Source: (Asian Development Bank, 2014)

Based on the Figure 2 above Thailand continues to be the best player in overall for 4 consecutive years, among participating countries, Thailand has the highest average score followed by Singapore and Malaysia. While Indonesia is in a position after Malaysia and above Vietnam which is relatively in the economy has recently developed. This clearly proves that it is still weak and that the principles of GCG have not been fully implemented in all SOEs.

Based on those phenomenon above, it can be concluded that the purpose of this study is first to determine the effect of solvency/leverage interpreted by DER on SOEs profitability, second to investigate empirically how far the activity ratio through TATO affects the profitability of SOEs and third to find out how far GCG through the Audit Committee indicator affects the profitability of SOEs and at the same time this research will contribute to enrich the literature on the profitability of SOEs that are influenced by these three variables and finally, this study aims to draw implications from the results derived which will serve as recommendations to increase SOEs' profitability.

\section{LITERATURE REVIEW Company's Performance}

Financial performance is an illustration of the achievement of the company's success can be interpreted as The results that have been achieved for various activities that have been carried out. It can be explained that financial performance is an analysis carried out to see the extent to which company that has implemented using the rules of financial implementation well and correctly. According to Udemy (2018) some financial ratios are often used to measure company's performance.

\section{Liquidity ratio}

The liquidity ratio aims to find out how far the company's ability to pay off short-term obligations. This ratio shows how far the wealth in this case is the current assets which is easy to use to pay liabilities namely current debt. The liquidity ratio consists of Current ratio is the ratio between current assets and current debt. This ratio calculation aims to find out how far the actual amount of current assets of the company can guarantee debt to short-term creditors. The higher the ratio means the more secure the company's debts 
to creditors.

\section{Profitability ratio}

This ratio illustrates the company's ability to make a profit through all capabilities, and available resources such as sales activities, cash, capital, number of employees, number of branches, and so on. Profitability ratios consist of:

a) Net profit margin

Net profit margin is the ratio or comparison between net profit (net profit or earnings after tax) with sales.

b) ROA

ROA is a comparison between net income and total assets of a company. The purpose of calculating this ratio is to find out how far the assets used in making profits. The purpose of calculating this ratio is to find out how far assets are used to make profits.

c) ROE

ROE is the ratio between net profit and total equity or own equity. This ratio aims to find out how far the results obtained from capital investment.

\section{Activity ratio}

Activity Ratio indicates the level of activity of a company's assets, measuring how fast the post or asset account rotates in a period. This ratio consists of:

a) Total Assets Turnover

This ratio shows total asset turnover measured by sales volume, in other words how far the ability of all assets to create sales.

b) Inventory Turnover

Inventory Turnover is a comparison between sales and inventory, which shows how many times the inventory has been spinning in 1 year.

\section{Solvency ratio}

This ratio describes the company's ability to pay its longterm obligations or obligations when the company is liquidated. This ratio consists of:

a) Debt to Asset Ratio

The ratio of liabilities to assets is the ratio between total liabilities and total assets of the company. This ratio shows how much debt is used to finance the company assets.

b) Debt to Equity Ratio

The debt to equity ratio is the ratio between total debt and total equity of the company.

\section{Corporate Governance}

In principle, corporate governance is a system where the company's business is directed and controlled. The government determines the distribution of rights and respon- sibilities among companies, such as boards, managers, and others as stakeholders (Organisation for Economic Cooperation and Development, 2015). Brickley and Zimmerman (2010) define corporate governance broadly as a system of laws, regulations, institutions, markets, contracts, and company policies and procedures (such as internal control systems, policies, and budgets) that direct and influence the actions of top-level decision makers in company (shareholders, board of directors, and executives).

Furthermore, Clarke (2011) defines corporate governance as a whole set of legal, cultural and institutional arrangements that determine what can be done by public companies, who controls the company, how the control is carried out, and how the risks and results of the activities carried out it is allocated. Hidayah (2017) defines good corporate governance as a collection of customary processes, policies, laws and institutions that influence the company by conducting direction, administration, and control. Haslinda, Alia, and Faizah (2016) Herdjiono and Mega (2017) in their research on corporate governance took 5 (five) dimensions.

\section{The board of commissioners}

The board of commissioners is the organ of the Company in charge of carrying out supervision in general and/or specifically in accordance with the articles of association and advising the directors.

\section{Board of directors}

The board of directors is a control centre in the company and this board has the responsibility for responsibility for health and the company's long-term success.

\section{Audit committee}

The audit committee is a group of people appointed by the board of commissioners, responsible for maintaining the auditor's independence from management.

\section{Institutional ownership}

Institutional ownership is the total number of shares owned by the institution. The existence of institutional ownership can monitor their increase in investment professionally so that the level of control over management is very high, which in turn can reduce the potential for fraud.

\section{Managerial ownership}

Managerial ownership is a shareholder of the company where shares are owned by the management of the company who actively participates in the decision making of the company (Director and Commissioner). This is measured by the percentage of shares owned by management. 


\section{RESEARCH METHODOLOGY}

The type of research used is descriptive and verification research on the effect of solvency, activity and implementation of GCG on the profitability of the company. This research is used as a research location, namely the IDX located on Jl. Jend. Sudirman Kav 52-53, South Jakarta 12190, Indonesia.

\section{Sample}

This study uses a quantity data sample obtained from the IDX website www.idx.co.id and the company's website which the data is examined using purposive sampling method, in the form of sampling with criteria in accordance with certain considerations. The selection of samples of annual financial report data is only from State Owned Enterprises registered in Indonesia Stock Exchange in the 2012-2017 period. The number of samples in this study were 14 companies.

\section{Analysis Data Method}

Determination of Data Model : Determination of the model aims to determine whether the test is suitable with the existing data model. There are 3 panel data test models conducted before performing regression analysis, namely chow test, langrange multiplier test and hausman test and the test results are then used to determine the use of analytical methods, namely Random Effect, Common Effect or Fixed Effect. To determine the right model, the following tests are carried out.

\section{Chow test}

Chow Test is a test to determine whether fixed effect model or PLS is more precise to use in statistic research model. The hypothesis in the chow test is as follows:

HO: Using Common Effect (CE) model.

H1: Using Fixed Effect (FE) model.

The test is done by seeing the probability value $F$-stat, if the value of F-stat prob is smaller than alpha so the the research model is more precise using FE model.

\section{Lagrange multiplier test}

Lagrange Multiplier (LM) Test is a test which is done to determine whether RE model or PLS is more precise to use. Hypothesis in LM test as follows:

H0: Using PLS model.

H1: Using Random Effect (RE) model.

To determine which hypothesis that is accepted, so it is seen by probability value of chi-square. If chi-square prob value is smaller than alpha so regression model is precise using RE model.

\section{Hausman test}

Hausman Test is a test which is done to determine whether FE model or RE is more precise to use. Hypothesis in Hausman Test as follows:

H0: Using RE model.

H1: Using FE model.

To determine which hypothesis which is accepted, it can be seen from $F$-stat probability value, if value of $F$-stat prob is smaller than alpha so the regression model is more precise to use FE model.

\section{Analysis of Multiple Linear Regression}

Multiple linear regression analysis is testing a linear relationship between two or more independent variables with the dependent variable. This analysis is conducted to determine the direction of the relationship between the independent variable and the dependent variable, whether each independent variable is positively or negatively related. Data analysis method used to measure the influence of solvancy, activity, and implementation of good corporate governance on company that is statistical analysis in the form of testing hypothesis using statistical tests. The statistical analysis used in this study is a multiple linear regression equation which is formulated as follows:

$$
\mathrm{ROA}_{\mathrm{it}}=\mathrm{a}+\mathrm{b}_{1} \mathrm{DER}+\mathrm{b}_{2} \text { TATO }+\mathrm{b}_{3} \mathrm{GCG}+\mathrm{e}
$$

Keterangan:

$i$ :Total of Company

$t:$ 2012-2017 period

ROA : Return on Assets

DER : Debt to Equity Ratio

TATO : Total Assets Turnover

e : Error

\section{Determination Coefficient ( $R^{2}$ Test)}

variation of the value of the dependent variable can be explained by the variation of the values of the independent variables. $R^{2}$ values will show how much $\mathrm{X}$ will affect the movement of Y. The bigger of the $R^{2}$ results is better because this shows that the better the independent variable will explain the dependent variable.

\section{Partial Regression Coefficient Test ( $t$ test)}

Statistical test $t$ basically shows how far the influence of an explanatory/independent variable individually in explaining the variation of the dependent variable (Ghozali, 2018). Partial testing of the independent variables used in this study are: 
a. If the $t$-count obtained from the processing value is bigger than $t$ table, it can be concluded that there is a partial effect between the independent variable and the dependent variable.

b. If the $t$-count obtained from the processing value is smaller than $t$ table, it can be concluded that there is no partial effect between the independent variable and the dependent variable.

\section{Simultaneous Regression Coefficient Test ( $F$ Test)}

$F$ test is used to measure whether all independent variables together have a significant effect on the dependent variable. Simultaneous testing is done by comparing the level of significance of $F$ from the test results with the significance value used in this study. Simultaneous testing of the independent variables used in this study are:

a. If the calculation obtained from the processing value is bigger than $F$ table, it can be concluded that there is a simultaneous influence between all independent variables with the dependent variable. b. If the calculation obtained from the processing value is smaller than the $F$ table value, it can be concluded that there is no simultaneous effect between all independent variables with the dependent variable.

\section{RESULTS}

\section{Determination of Regression Model}

Determination of the model aims to determine whether the test is suitable with the existing data model. There are 2 panel data test models conducted before performing regression analysis, namely chow test, and hausman test and the test results are then used to determine the use of analytical methods, namely Random Effect, Common Effect or Fixed Effect.

\section{Chow Test}

Chow Test is used to determine whether the research model is more suitable to use CE method or FE method. The following below presents a table of the results of the chow tests that have been carried out.

TABLE 1. The results of the chow tests

\begin{tabular}{llll}
\hline \hline Effects Test & Statistic & d.f. & Prob. \\
\hline Redundant Fixed Effects Tests & & & \\
Equation: Untitled & & & \\
Test cross-section fixed effects & & & \\
Cross-section $F$ & 11.968104 & $(13,67)$ & 0.0000 \\
Cross-section Chi-square & 100.851914 & 13 & 0.0000 \\
\hline \hline
\end{tabular}

Based on the results of the Chow test in Table 1, shows the value of the Chi-square Cross-section probability of 0.0000 is smaller than 0.05 , then the right model in estimating panel data is Fixed Effect.

\section{Hausman test}

Hausman test is used to determine whether the research method is more precise using FE method or RE method. The following below presents a table of the results of the Hausman tests that have been carried out.

TABLE 2. The results of the Hausman tests

\begin{tabular}{llll}
\hline \hline Test Summary & Chi-Sq. Statistic & Chi-Sq. d.f. & Prob. \\
\hline Correlated Random Effects - Hausman Test & & & \\
Equation: Untitled & & & \\
Test cross-section random effects & & 3 & 0.4486 \\
Cross-section random & 2.650966 & 3 \\
\hline \hline
\end{tabular}

Based on the results of the Hausman test in Table 2, shows a Chi-square Cross-section probability value of 0.4486 greater than then the right model in estimating panel data is the Random Effect. Thus, in this study the regression model will be used is the Random Effect model, although the chow test shows fixed effects that should be used in testing panel data.

\section{Analysis of Multiple Linear Regression}

The following is the presentation and results of multiple linear regression analysis. 
TABLE 3. The results of multiple linear regression

\begin{tabular}{lllll}
\hline \hline Variable & Coefficient & Std. Error & $\boldsymbol{t}$-Statistic & Prob. \\
\hline C & -5.042956 & 3.835788 & -1.314712 & 0.1924 \\
DER & -1.830242 & 0.635721 & -2.879000 & 0.0051 \\
TATO & 8.137540 & 2.388701 & 3.406680 & 0.0010 \\
GCG_KA & 1.784139 & 0.710770 & 2.510149 & 0.0141 \\
\hline \hline
\end{tabular}

$$
\mathrm{ROA}=\mathrm{C}(1)+\mathrm{C}(2)^{*} \mathrm{DER}+\mathrm{C}(3)^{*} \mathrm{TATO}+\mathrm{C}(4)^{*} \mathrm{GCG}-\mathrm{KA}+[\mathrm{CX}=\mathrm{R}]
$$

$$
\mathrm{ROA}=-5.04295-1.83024^{*} \mathrm{DER}+8.137540^{*} \mathrm{TATO}+1.7841394^{*} \mathrm{GCG}-\mathrm{KA}+[\mathrm{CX}=\mathrm{R}]
$$

Based on the results of the analysis in Table 3, so it can be made the multiple regression equations which are formulated as follows: The interpretation of the equation of the multiple linear regression model above is as follows:

1. Constants

A constant of -5.04295 means that if all the independent variables are 0 (zero), then the ROA is negative at -5.04295 .

2. DER Regression Coefficient

DER Regression Coefficient is negative at 1.83024. This illustrates that every increase of $1 \%$ DER, the ROA of the company will decrease by 1,83024 , with the assumption the other influenced variable is remaining.

3. TATO Regression Coefficient

A positive TATO Regression Coefficient of 8.137540 this il- lustrates that every $1 \mathrm{x}$ TATO increase then ROA will increase by 8.137540 , with the assumption the other influenced variable is remaining 4. Audit Committee Regression

The Audit Committee Regression Coefficient is positive at $1,784,139$, this illustrates that every increase of 1 Audit Committee then ROA will increase by 1,784139 with the assumption the other influenced variable is remaining.

\section{Determination Coefficient Test $\left(R^{2}\right)$}

Test of determination or accuracy of the googness of fit model to measure the size of the model's ability to explain the dependent variable. The small values of $R^{2}$ means the ability of independent variables in explaining dependent variables are very limited.

TABLE 4. The results of Determination Coefficient Test $\left(R^{2}\right)$

\begin{tabular}{llll}
\hline \hline$R$-squared & 0.217532 & Mean dependent var & 1.456595 \\
Adjusted $R$-squared & 0.188190 & S.D. dependent var & 4.282474 \\
S.E. of regression & 3.858531 & Sum squared resid & 1191.061 \\
$F$-statistic & 7.413549 & Durbin-Watson stat & 1.382925 \\
Prob $(F$-statistic) & 0.000192 & & \\
\hline \hline
\end{tabular}

Based on the results presented in Table 4 , the $R$-squared value is 0.217532 or $21.75 \%$. This shows that the independent variables DER, TATO, and GCG are able to explain the dependent variable ROA of 0.217532 or $21.75 \%$, while the remaining $78.25 \%$ is explained by other variables outside the research.

\section{Partial Regression Coefficient Test ( $t$ test)}

The test performed to test the independent variable is a partial test ( $t$ test). This test aims to determine the effect of independent variables on the research model. Referring to the table resulting from multiple linear regression analysis, the DER variable has a probability value of 0.0051 . If the probability is $<0.05$ then $\mathrm{H} 1$ is accepted, and if the probability is $>0.05$ then $\mathrm{H} 1$ is rejected. Based on this, the probability value is less than $0.05(0.0051<0.05)$ so H1 is accepted. Thus it can be concluded that the presence of DER has a significant negative effect on ROA in State Owned Enterprises registered on the IDX.

Referring to the table resulting from multiple linear regression analysis, the TATO variable has a probability value of 0.0010 . If the probability is $<0.05$ then $\mathrm{H} 1$ is accepted, and if the probability is $>0.05$ then $\mathrm{H} 1$ is rejected. Based on this, the probability value is smaller than $0.05(0.0010<0.05)$ then $\mathrm{H} 1$ is accepted. Thus it can be concluded that TATO has a significant effect on ROA in State Owned Enterprises 
registered on the IDX. Referring to the results table of multiple linear regression analysis, the Audit Committee variable has a probability value of 0.0141 . If the probability is $<0.05$ then $\mathrm{H} 1$ is accepted, and if the probability is $>0.05$ then $\mathrm{H} 1$ is rejected. Based on this, the probability value is smaller than $0.05(0.0141<0.05)$ so $\mathrm{H} 1$ is accepted. Thus it can be concluded that the Audit Committee has a significant effect on ROA in State Owned Enterprises registered on the IDX.

\section{Simultaneous Regression Coefficient Test ( $F$ Test)}

Based on the table on the coefficient of determination $\left(R^{2}\right)$, the probability value ( $F$-statistic) is 0.000192 . If the probability is $<0.05$ then $\mathrm{H} 1$ is accepted, and if the probability is $>0.05$ then $\mathrm{H} 1$ is rejected. Based on this, the probability value is smaller than $0.05(0.000192<0.05)$ then $\mathrm{H} 1$ is accepted. Thus it can be concluded that DER, TATO, and Audit Committee have a significant effect on ROA in State Owned Enterprises registered on the IDX.

\section{DISCUSSION}

\section{The Effect of DER on ROA}

Based on the results in the previous table, it was found that DER had a significant negative effect on ROA. The negative influence of the DER implies that the debt made by the company has a direct impact on the profitability of State Owned Enterprises registered on the Indonesian stock exchange. In theory, the higher the DER means to indicate that the total debt is high which has an interest charge which has an impact on the reduction in company profits.

This matter is supported by the results of the study (Eriotis, Frangouli, \& Ventoura-Neokosmides, 2002) they concluded that financing investments using retained profits are more profitable than using borrowed funds. This is in line with (Rahman, 2017) stateding there is a negative relationship between the two solvency ratios and ROA. the same thing stated by (Alarussi \& Alhaderi, 2018) stateding that the results show also negative relationships between debt equity ratio and leverage ratio and profitability and supported by the results of the study (Ibhagui \& Olokoyo, 2018) the magnitude of the negative effects of leverage on ROA for smallsized firms is generally higher than the magnitude of the insignificant impact of leverage on ROA for large-sized firms. This suggests that when leverage has a negative impact on ROA, the impact is more pronounced on small-sized companies. This happens in real terms that the average DER of SOEs each year is relatively experiencing an increase from 2012-2017 which causes the profitability decreasing very significantly (the data can be seen in the appendix).

\section{The Effect of TATO on ROA}

Base on the results shows that TATO had a significant effect on ROA. This illustrates that State Owned Enterprises not yet effective in using their assets to generate total net sales where fast asset turnover is not followed by high sales so which causes the profitability decreasing significantly enough.

This is supported by the results of research(Andreani, 2014; Enekwe, 2015) which is stated that total asset turnover ratio has a positive influence on profitability. In fact (Warrad \& Rania, 2015) the study shows a significant impact of total assets turnover ratio on the ROA. and Hence, changes in ROA can be explained by total assets turnover ratio. the same thing stated by Alarussi and Alhaderi (2018) that the results show strong positive relationships between total sales, working capital and assets turnover ratio and profitability. This happens in real terms that the average TATO of SOEs each year is relatively experiencing an decreasing from 2012-2017 which causes the profitability decreasing enough significantly (the data can be seen in the appendix).

\section{The Effect of GCG on ROA}

Based on the results of this study, the GCG variable with the Audit Committee indicator has a significant effect on ROA. This illustrates that the audit committee is expected to be able to create financial reports that are relevant and free from manipulation of any party so that it can be used as an evaluation for management. The audit committee is also expected to create a transparent business environment and later it can improve the company's performance. The audit committee also has a role as connector between the external auditor and the internal auditor. With the supervision carried out by the audit committee on the company's internal control, it will minimize the occurrence of unhealthy actions taken by management for its own sake. That way, the company's ROA will increase.

This is supported by the results of research (Alley et al., 2016; Kallamu \& Saat, 2015; Mondal \& Ghosh, 2012) stated that corporate governance significantly affects financial performance. In fact the results of research by (Naimah, 2017) stated that audit committee meeting positively influence profitability.

\section{The Effect of DER, TATO, and GCG on ROA}

Based on the results of this study, the variables DER, TATO, and GCG with the Audit Committee indicators simultaneously have a significant effect on ROA. This illustrates that the higher DER means it indicates a high total debt has an interest charge which has an impact on the reduction in com- 
pany profits. Likewise, the effectiveness of the use of assets of State Owned Enterprises registered on the Indonesia Stock Exchange will result in total net sales where asset turnover is quickly followed by high sales so it makes profits. The audit committee also plays a role in increasing the ROA of the company by carrying out optimal supervision of the management in carrying out the company's operations. This matter is supported by the results of research Kumalasari and Pratikto (2018) GCG has a significant positive effect on ROA. When GCG has increased then ROA will also increase, so that performance will also give good results. In fact the result of study Jereb (2013) stateding that companies with higher level of implementation of principles of corporate governance and better practice of corporate governance are more profitable and have better performance. Therefore, if companies want to increase their performance, survive in global market, become more competitive, profitable, attract investors, customers and raise capital at lower price, they must implement corporate governance principles and standards in their strategy and decision making process.

\section{CONCLUSION}

1. Based on the result of the study, it is concluded that DER has an effect on ROA. The higher the DER, the lower the profitability of the company due to the interest expense borne.

2. Based on the result of the study, it is concluded that TATO affects ROA. This illustrates the effective use of assets from State Owned Enterprises to produce optimal sales.

3. Based on the results of the GCG research, the Audit Committee indicators have a significant effect on ROA. This illustrates that the more effective role of the audit committee in State Owned Enterprises that supervise management performance will have an impact on the company's profitability.

4. It is concluded that DER, TATO, and GCG with the Audit Committee indicator have a significant effect on ROA on State Owned Enterprises registered on the IDX.

\section{IMPLICATIONS}

1. For further researchers, this research is limited to using internal factors of the company, external factors such as market to price (Price to Book Ratio) and macroeconomics such as (exchange rates, inflation, and stock prices), have not been used as a measure in this study.

2. For investors

Investors should be not only paying attention to the company's ROE value, but ROA and other fundamental ratios must be considered.

3. For state-owned enterprises companies in order to reduce the level of debt and should be the efficient use of assets as well as still maintaining and enhancing competent audit committees.

\section{REFERENCES}

Alarussi, A. S., \& Alhaderi, S. M. (2018). Factors affecting profitability in Malaysia. Journal of Economic Studies, 45(3), 442-458. doi:https://doi.org/10.1108/jes-05-2017-0124

Alfian, \& Tresna, M. G. (2017). The influence of company's age and owner's/manager's education on the use of accounting information in small and medium enterprises. International Journal of Business and Administrative Studies, 3(2), 64-71. doi:https://doi.org/10.20469/ijbas.3.10003-2

Alley, I. S., Adebayo, A. L., \& Oligbi, B. O. (2016). Corporate governance and financial performance nexus: Any bidirectional causality? International Journal of Management and Economics, 50(1), 82-99. doi:https://doi.org/10.1515/ijme-2016 $-0013$

Andreani, C. B. L. (2014). Analisis faktor-faktor yang mempengaruhi audit delay. Diponegoro Journal of Account, 3(2), 1-10.

Ariyanti, F. (2017). 24 bumn rugi, sri mulyani minta menteri rini perkuat tata kelola. Retrieved from https://urlzs .com/ MpvY1 (accessed on 30 August, 2017)

Asian Development Bank. (2014). Asean corporate governance scorecard country reports and assessments 2013-2014. Retrieved from https://urlzs. com/u4LUe (accessed on 13 June, 2017)

Bahri, C., Mahsina, S. E., \& Poniwati, M. (2017). The influence of undervaluation, free cash flow, leverage and dispersion of ownerships toward company's stock repurchase (An empirical study of Indonesia stock exchange public listed companies). Journal of Administrative and Business Studies, 3(5), 235-247. doi:https://doi.org/10.20474/jabs-3.5.3

Brickley, J. A., \& Zimmerman, J. L. (2010). Corporate governance myths: Comments on armstrong, guay, and weber. Journal of Accounting and Economics, 50(2-3), 235-245.

Bukti Konsistensi Pengelolaan Keuangan. (2017). Good corporate governance. Retrieved from https ://urlzs . com/AsGCi (accessed on 14 July, 2018) 
Bursa Efek Indonesia. (2018). Ikhtisar pasar. Retrieved from https://urlzs . com/vHqcf

Cadbury, A. (1992). The financial aspects of corporate governance. London, UK: Committee on the Financial Aspects of Corporate Governance.

Choi, Y.-S., O'Hanlon, J. F., \& Pope, P. F. (2006). Conservative accounting and linear information valuation models. Contemporary Accounting Research, 23(1), 73-101. doi:https://doi.org/10.1506/7y8h-c8pp-8hfr-831w

Cîrciumaru, D., Siminica, M., \& Marcu, N. (2010). A study on the return on equity for the Romanian industrial companies. Annals of University of Craiova-Economic Science Series, 2(5), 38-45.

Clarke, D. C. (2011). Nothing but wind? The past and future of comparative corporate governance. The American Journal of Comparative Law, 59(1), 75-110. doi:https://doi.org/10.5131/ajcl.2010.0016

Edward, D. (2015). Waspadai gagal bayar bumn di proyek infrastruktur. Retrieved from https://urlzs.com/hnMpY (accessed on 15 June, 2018)

Endang, K., \& Risal. (2017). The effect of investment decision financing decision dividend payment policy and company size. Journal of Administrative and Business Studies, 3(2), 105-113. doi:https://doi.org/10.20474/jabs-3.2.5

Enekwe, C. I. (2015). The relationship between financial ratio analysis and corporate profitability: A study of selected quoted oil and gas companies in Nigeria. European Journal of Accounting, Auditing and Finance Research, 3(2), 17-34.

Eriotis, N. P., Frangouli, Z., \& Ventoura-Neokosmides, Z. (2002). Profit margin and capital structure: An empirical relationship. Journal of Applied Business Research, 18(2), 85-88. doi:https://doi.org/10.19030/jabr.v18i2.2118

Ghozali, I. (2018). Aplikasi analisis multivariete dengan program IBM SPSS 23. Jakarta, Indonesia: Badan Penerbit Universitas Diponegoro.

Gitman, L. J. (2002). Fundamentals of investing. New Dehli, India: Pearson Education.

Hagel, J., Brown, J. S., \& Davison, L. (2010). The best way to measure company performance. Harvard Business Review, 4(6), 56-60.

Haslinda, Y., Alia, J., \& Faizah, D. (2016). Corporate governance and corporate social responsibility disclosures: An emphasis on the CSR key dimensions. Journal of Accounting and Auditing: Research \& Practice, 2(5), 1-14.

Herdjiono, I., \& Mega, S. I. (2017). The effect of corporate governance on the performance of a company: Some empirical findings from Indonesia. Journal of Management and Business Administration Central Europe, 25(1), 33-52. doi: https://doi.org/10.7206/jmba.ce.2450-7814.188

Hermuningsih, S. (2013). Pengaruh profitabilitas, growth opportunity, struktur modal terhadap nilai perusahaan pada perusahaan publik di Indonesia. Bulletin of Monetary Economics and Banking, 16(2), 1-22. doi:https://doi.org/10 .21098/bemp.v16i2.27

Hidayah, N. (2017). The effect of good corporate governance and intellectual capital on the quality of financial reporting (case study of banking companies in indonesia stock exchange). Corporate Governance and Financial Reviews, 2(2), 50-55.

Ibhagui, O. W., \& Olokoyo, F. O. (2018). Leverage and firm performance: New evidence on the role of firm size. The North American Journal of Economics and Finance, 45(5), 57-82. doi:https://doi.org/10.1016/j.najef.2018.02.002

Jereb, B. (2013). Risk assessment model respecting segments of the public. Montenegrin Journal of Economics, 9(3), 75-94.

Kallamu, B. S., \& Saat, N. A. M. (2015). Audit committee attributes and firm performance: Evidence from Malaysian finance companies. Asian Review of Accounting, 23(3), 206-231. doi:https://doi.org/10.1108/ara-11-2013-0076

Khan, M. N., \& Khokhar, I. (2015). The effect of selected financial ratios on profitability: An empirical analysis of listed firms of cement sector in Saudi Arabia. Quarterly Journal of Econometrics Research, 1(1), 1-12. doi:https://doi.org/ 10.18488/journal.88/2015.1.1/88.1.1.12

Kiel, G. C., \& Nicholson, G. J. (2003). Board composition and corporate performance: How the Australian experience informs contrasting theories of corporate governance. Corporate Governance: An International Review, 11(3), 189-205. doi: https://doi.org/10.1111/1467-8683.00318

Kumalasari, D., \& Pratikto, H. (2018). Good corporate governance affects on corporate value through return on equity and return on asset of manufacture company. KnE Social Sciences, 3(3), 114-126. doi:https://doi.org/10.18502/ kss.v3i3.1878

Liu, D., Fisher, G., \& Chen, G. (2018). CEO attributes and firm performance: A sequential mediation process model. Academy of Management Annals, 12(2), 789--816. doi:https://doi.org/10.5465/annals.2016.0031 
Mondal, A., \& Ghosh, S. K. (2012). Intellectual capital and financial performance of Indian banks. Journal of Intellectual Capital, 13(4), 515-530. doi:https://doi.org/10.1108/14691931211276115

Naimah, Z. (2017). The role of corporate governance in firm performance. In SHS Web of Conferences, New York, NY.

Naseem, M. A., Xiaoming, S., Riaz, S., \& Rehman, R. U. (2017). Board attributes and financial performance: The evidence from an emerging economy. The Journal of Developing Areas, 51(3), 281-297. doi:https://doi.org/10.1353/jda.2017.0073

Organisation for Economic Co-operation and Development. (2015). Oecd guidelines on corporate governance of state-owned enterprises. Retrieved from https://urlzs.com/kLgY9 (accessed on 15 August, 2017)

Peraturan Menteri Bumn. (2012). Peraturan menteri bumn per-12/mbu/2012 tanggal 24 agustus 2012 organ pendukung dewan komisaris /dewan pengawasan bumn. Retrieved from https://urlzs.com/qQnSj (accessed on 15 August, 2017)

Pitoko, R. A. (2018). Bumn harus cerdas mengelola aset. Retrieved from https://urlzs.com/BMcjp (acessed on 15 July, 2019)

Primadhyta, S. (2017). Ojk: Praktik GCG perusahaan Indonesia masih tertinggal. Retrieved from https : //urlzs . com/h3oLY (accessed on 15 July, 2018)

Putra, A. S., \& Nuzula, N. F. (2017). Pengaruh corporate governance terhadap manajemen laba pada perusahaan perbankan yang terdaftar di bursa efek Indonesia. Jurnal Ekonomi Bisnis dan Akuntansi Ventura, 23(2), 103-112.

Rahman, A. A. A. A. (2017). The relationship between solvency ratios and profitability ratios: Analytical study in food industrial companies listed in Amman Bursa. International Journal of Economics and Financial Issues, 7(2), 86-93.

San, O. T., \& Heng, T. B. (2011). Capital structure and corporate performance of Malaysian construction sector. International Journal of Humanities and Social Science, 1(2), 28-36.

Song, Y., Cai, J., \& Feng, T. (2017). The influence of green supply chain integration on firm performance: A contingency and configuration perspective. Sustainability, 9(5), 763.

Sulashvili, G., Pailodze, N., Abralava, A., Kutateladze, R., M., S., Murvanidze, I., ... Kipiani, S. (2017). The issues regarding the refinement of effective management of the company. International Journal of Business and Economic Affairs, 2(3), 206-210. doi:https://doi.org/10.24088/ijbea-2017-23005

Sundar, C. S., \& Al Harthi, F. N. S. (2015). Impact of capital structure on firm's profitability with reference to companies listed on Muscat Securities Market (MSM). International Journal of Business and Administrative Studies, 1(1), 23 - 28. doi:https://doi.org/10.20469/ijbas.10004

Tailab, M. (2014). The effect of capital structure on profitability of energy American firms. International Journal of Business and Management Invention, 3(12), 54-61.

Tomsic, D. (2013). Towards a relational view of corporate governance. Montenegrin Journal of Economics, 9(2), 71-80.

Udemy. (2018). Accounting \& financial statement analysis: Complete training. Retrieved from https://urlzs. com/jviHq (accessed on 15 April, 2018)

Warrad, L., \& Rania, A. (2015). The impact of activity ratio among industrial sectors' performance: Jordanian case. Research Journal of Finance and Accounting, 6(6), 173-178. doi:https://doi.org/10.17265/1548-6583/2015.02.001

Willy, S. (2017). Analysis of financial ratios to measure the company's performance in the sectors of consumer goods at Pt. Nippon Indosari Corpindo, Tbk and Pt. Mayora Indah, Tbk. International Journal of Business and Economic Affairs, 2(1), 45-51. doi:https://doi.org/10.24088/ijbea-2017-21006

Wiyanti, S. (2015). Ini 23 bumn penerima PMN di 2016, PLN paling banyak rp 10 triliunno title. Selasa, 5(6), 15-42.

World Bank. (2017). Indonesia Public Expenditure and Financial Accountability (PEFA). (accessed on 15 June, 2017) doi: https://urlzs.com/VNMTY

Zabri, S. M., Ahmad, K., \& Wah, K. K. (2016). Corporate governance practices and firm performance: Evidence from top 100 public listed companies in Malaysia. Procedia Economics and Finance, 35, 287-296. doi:https://doi.org/10.1016/ s2212-5671(16)00036-8

Zahra, S. A., \& Hayton, J. C. (2008). The effect of international venturing on firm performance: The moderating influence of absorptive capacity. Journal of Business Venturing, 23(2), 195-220. doi:https://doi.org/10.1016/j.jbusvent.2007.01 .001 